\title{
Percutaneous Pedicle Screws Positioning by means of the "Scotty Dog" Imaging Monitoring Technique in Spine Surgery: A Case Series
}

\section{Posicionamento de parafuso pedicular percutâneo por meio do método Scotty Dog de monitoramento de imagem em cirurgia de coluna: uma série de casos}

\author{
Adriano Scaff Garcia ${ }^{1}$ José Antonio Braz Galvão ${ }^{2}$ Piero Scarparo ${ }^{2}$ Humberto Bortolo Neto ${ }^{2}$ Pil Sun Choi ${ }^{2}$ \\ ${ }^{1} \mathrm{MD}, \mathrm{MSc}$, Physician, Centro Especializado em Coluna e Dor, Ribeirão \\ Preto, SP, Brazil \\ $2 \mathrm{MD}$, Physician, Centro Especializado em Coluna e Dor, Ribeirão \\ Address for correspondence Adriano Scaff Garcia, MD, MSc, Av. \\ Antonio Diederichsen, 400 - sala 510, Ribeirão Preto, SP, Brazil CEP: \\ 14020-250 (e-mail: adrianoscaff@gmail.com).
} Preto, SP, Brazil; Orthopedic Surgeon, Hospital das Clínicas, Universidade de São Paulo, São Paulo, SP, Brazil

Arq Bras Neurocir 2016;35:31-38.

\section{Abstract \\ Keywords \\ - fluoroscopy \\ - surgical diagnostic techniques \\ - percutaneous discectomy \\ - spine \\ - diagnostic imaging}

Objectives Vertebrae, when looked at in x-rays with oblique incidence $\left(45^{\circ}\right)$, seem similar in shape to a Scottish Terrier dog. The "Scotty Dog" incidence is commonly used in spinal pain treatments such as radiofrequency and transforaminal blockages for correct insertion of the needle, because it allows complete visualization of the pedicle. The objective is to describe a series of cases of spinal surgery using the "Scotty Dog" monitoring technique and to evaluate safety.

Methods In this study, we describe all consecutive patients operated by the same surgeon from August 2011 to August 2012 using the "Scotty Dog" technique of fluoroscopic monitoring. Patients were operated for spondylolisthesis, lumbar canal stenosis, spinal disc herniations, and fractures. All patients underwent computed tomography (CT) after surgery to confirm the correct positioning of screws.

Results During the study period, 42 patients with a mean age of 64.5 years underwent operation, most of them for spinal disc herniation correction. In all cases, visualization of the pedicle was possible in all its length and no case of foramen invasion was registered. Surgical time was 98 minutes on average, with no need for transfusion or complications requiring admission to the ICU. There was one case of infection.

Conclusions The Scotty Dog technique for imaging monitoring of the spine provides easy visualization of the whole pedicle, allowing a safe screw insertion. In this case series, there was no case of foramen invasion. received

October 22, 2014

accepted

August 28, 2015

published online

February 15, 2016
DOI http://dx.doi.org/

10.1055/s-0035-1570494. ISSN 0103-5355.
Copyright $\odot 2016$ by Thieme Publicações License terms

Ltda, Rio de Janeiro, Brazil

(ㄷ) (i) $\fallingdotseq$ (요 


\section{Resumo}

Palavras-chave
- fluoroscopia
- técnicas de
diagnóstico por
cirurgia
- discotomia
percutânea
- coluna
vertebral
- diagnóstico por
imagem

Objetivos As vértebras, visualizadas pela incidência oblíqua $\left(45^{\circ}\right)$ nos raios- $X$, têm o formato de um cão da raça Scottish Terrier. A incidência Scotty Dog é usada em tratamentos de dor na coluna, como radiofrequência e bloqueios transforaminais, para correta inserção da agulha, porque permite completa visualização do pedículo. O objetivo deste trabalho é descrever uma série de casos de cirurgia de coluna usando a técnica de monitoramento Scotty Dog e avaliar segurança.

Métodos Todos os pacientes consecutivos operados pelo mesmo cirurgião de agosto de 2011 a agosto de 2012 usando a técnica Scotty Dog de monitoramento fluoroscópico foram descritos. Pacientes foram operados devido a espondilolistese, estenose do canal vertebral, hérnias e fraturas. Todos os pacientes foram submetidos a tomografia computadorizada após a cirurgia para confirmação do correto posicionamento dos parafusos.

Resultados No período do estudo, 42 pacientes foram operados, com média de idade de 64,5 anos, a maioria para correção de hérnia de disco. Em todos os casos, a visualização do pedículo foi possível em toda a sua extensão e não foi registrado caso de invasão do forame. O tempo de cirurgia foi de 98 minutos em média, sem necessidade de transfusões ou complicações exigindo internação em unidade de terapia intensiva. Houve um caso de infecção.

Conclusões A técnica Scotty Dog de monitoramento por imagem da coluna permite fácil visualização de todo o pedículo e inserção do parafuso com segurança, com nenhum caso de invasão foraminal nesta série de casos.

\section{Introduction}

The Scottish Terrier, also called the "Scottie" or "Scotty", is a small breed of dog known for its distinct shape, which is similar in format to vertebrae when visualized via $\mathrm{x}$-ray at an oblique incidence ( $\mathbf{- F i g . 1}$ ). At 45 degrees, it is possible to clearly see the dog's body parts corresponding to the pars interarticularis (neck), the transverse process (the Scotty dog's nose), the pedicle (eye), the superior (ear) and lower facet joint (leg). ${ }^{1,2}$ The oblique incidence is used to achieve an image resembling the Scotty Dog in interventional treatments for back pain, such as radio and transforaminal blocks ${ }^{2,3}$, since needle insertion is safer when viewing the pedicle completely. This type of visualization is also commonly used only for non-surgical procedures.

Minimally invasive surgery is increasingly replacing open surgery in all the medical specialties. The same holds true for spinal surgery, where percutaneous trans-pedicular fixation has been increasingly used in cases of degenerative diseases, fractures, or deformities. ${ }^{4-7}$ Traditional methods (fluoroscopic images in anterior-posterior and profile incidences), on the other hand, hinder the visualization of the pedicle in all its extension, which makes medialized insertion of screws difficult. ${ }^{8,9}$ Fluoroscopy in anterior-posterior (AP) view promotes a two-dimensional image, in which the medial part of the pedicle overlaps with part of the spinal canal. This is called the lateral recess ( - Fig. 2). Thus, it is difficult to verify that the screw has reached beyond the confines of the pedicle, invading the spinal canal, and placing structures at risk, such as the dural sac medially, nerve roots above and below, as well as vascular structures in the anterolateral area.
When performing minimally invasive surgery, surgeons need to compensate for the lack of direct visualization of the structures; thus, they deal with the problem using resources such as neuronavigation ${ }^{8}$, electromyography ${ }^{10}$, or intraoperative neurophysiological monitoring ${ }^{4}$, whereby a neurologist supervises the procedure and alerts as to whether nerve structures have been affected (nerve roots). It important to note, however, that costs of minimally invasive surgery become higher once these resources are added.

The visualization of the pedicle in blocking or radiofrequency procedures is usually made easier with oblique positioning of the fluoroscope. Starting in 2011, we began using the so-called Scotty Dog technique to better view the pedicle in its full extent and insert screws percutaneously in surgical arthrodesis with greater ease. With experience, this treatment allowed the application of the imaging monitoring method in percutaneous surgery as well, favoring the onset of this study.

The aim of this study is to describe a series of cases in which percutaneous pedicle screws were placed using the fluoroscopic monitoring technique known as Scotty Dog, and to verify the safety of this technique, by the ratio of canal and foramen invasion by screws.

\section{Materials and Methods}

The present study is an analysis of a case series of all patients consecutively operated on in the Hospital Especializado de Ribeirão Preto, between August 2011 and August 2012, by the same surgeon (ASG). The surgeries were indicated for spondylolisthesis, lumbar canal stenosis, disc herniation, and 


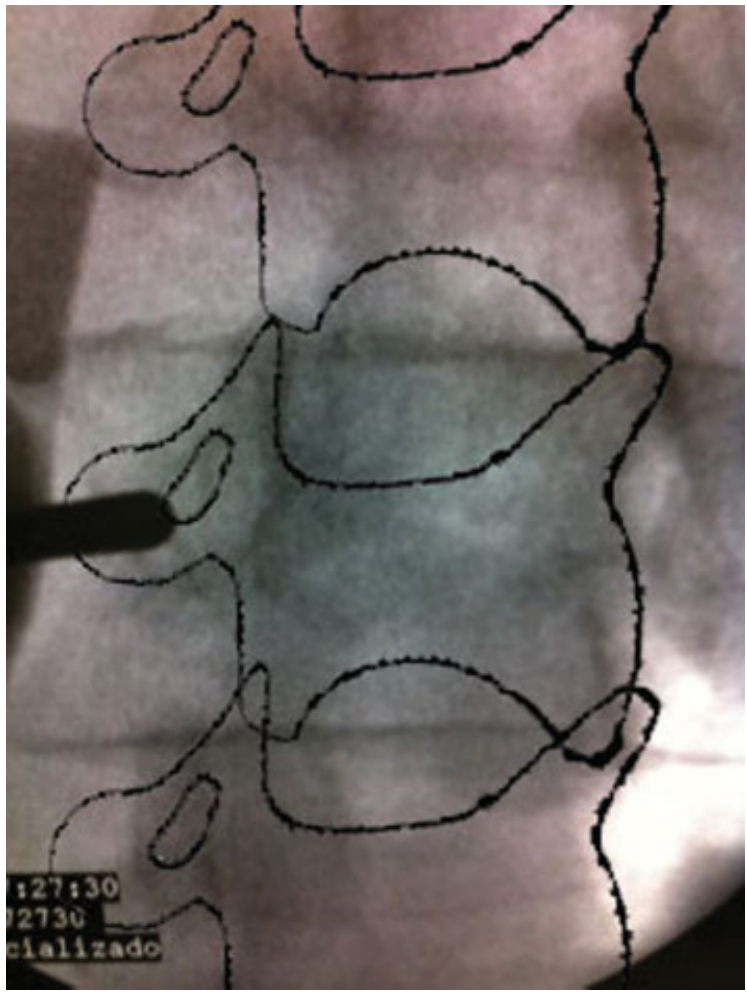

Fig. 1 Classic profile of the Scotty Dog outlined on an oblique view radiograph.

fractures. All the patients underwent surgery using the Scotty Dog fluoroscopic monitoring technique, as described below.

All patients were treated under private payment or medical insurance. They were informed about the surgical method and were verbally informed that surgery would be accompanied by fluoroscopy using an incidence that was different from the usual to facilitate visualization of the pedicle and for a safer screw insertion. All agreed to the procedure.
All patients underwent postoperative computed tomography $(\mathrm{CT})$ with bone window and three-dimensional reconstruction. We only included patients who were consecutively operated on in the same hospital by the same surgeon using a standard technique, as described below, with no age limit for inclusion in the study. We excluded patients without CT examination postoperatively.

We investigated and recorded patientś age at surgery, gender, duration of surgery, incidence of bleeding, need for blood transfusion, and hospitalization in the intensive care unit (ICU), as well as complications, such as infections and injuries to nervous structures.

\section{The Scotty Dog Monitoring Technique}

The patient is in the prone position. However, unlike the percutaneous surgical procedure commonly performed, instead of positioning the fluoroscope for anterior-posterior incidences, the Scotty Dog image technique is obtained on oblique incidence until adequate visualization of the figure of the Scotty Dog, delimiting the expected structures (transverse process, pedicle, upper and lower articular facets, foramen, and lateral recess), as shown in - Fig. 3.

In the case of pedicular instrumentation following a discectomy or decompression of the spinal canal, in other words, any intervention in the surgical act that requires prior incision, percutaneous placement of the screws is performed using the same incision. When there is no need for a previous incision, such as simple spine instrumentation in fractures, we use small incisions (of approximately $4 \mathrm{~mm}$ ) in the sites for each screw placement.

The next step is the drilling of the pedicle using the Scotty Dog fluoroscopic technique. Specific material for spinal percutaneous instrumentation (the Jamshidi needle) is necessary. After the initial perforation (guided by the oblique image), we check the depth of the needle in the profile image. When the anterior third of the vertebra is reached, we remove the central portion of the needle, which is

A
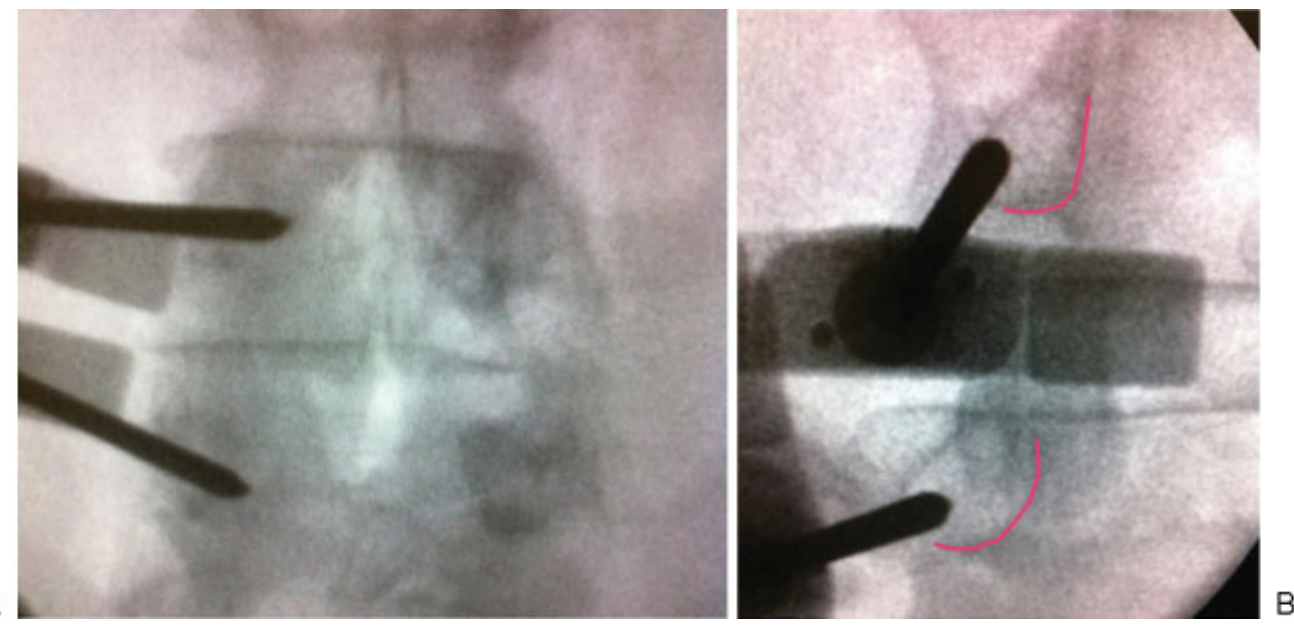

Fig. 2 Lumbar spine in surgical view (left), with no precision of pedicle borders. Lumbar spine in oblique surgical view (right), with precision of pedicle borders for screw insertion. Red curves show medial and foraminal borders of the pedicle. 

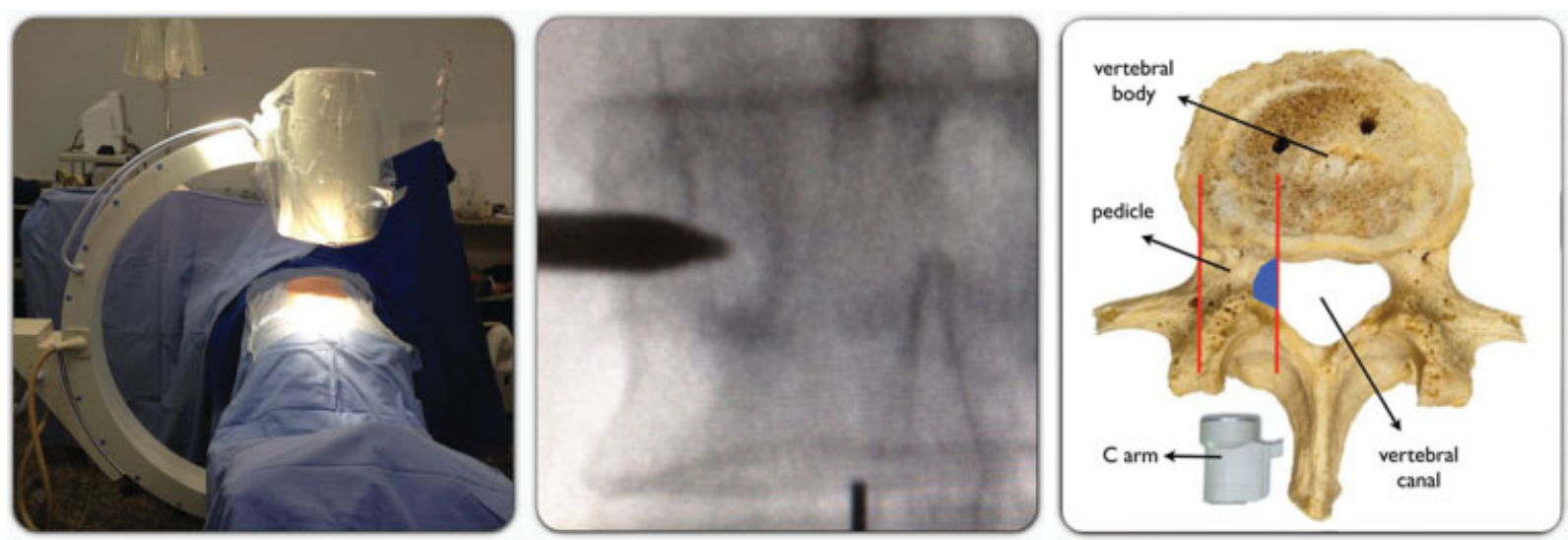

Fig. 3 Fluoroscope $\mathrm{C}$-arm positioned in the traditional anterior-posterior incidence (above) and in oblique incidence, as in the new technique (below), schematic illustration of the visualization and the obtained images with each.

cannulated for the passage of the guide wire. Checking again the position of the guide wire in the profile imaging, we remove the outer needle. At this time, we insert the cannulated pedicle screw, using specific instruments. After placing the desired number of screws, we proceed with mounting the system, as shown in - Fig. 4. Finalizing the surgery, we pass the rod through the hole and nuts are tightened (-Fig. 4), with contraction or distraction of the system.

\section{Results}

During the study period, 42 patients were admitted for percutaneous procedures in the spine with no sample losses. Among these, 21 (50\%) were women. The average age was 64.5 years (range: $39-82$ years). Indications for surgery were disc herniation correction in the majority $(54.8 \%)$ cases, as described in - Table 1. In all patients, percutaneous instrumentation was used, mostly at L4-L5, as shown in - Table 2.

It was possible to view the entire pedicle in all patients, and there was no case of invasion of the spinal canal or foramen (-Fig. 5). Surgical time was on average 98 minutes, ranging from 40 to 182 minutes.

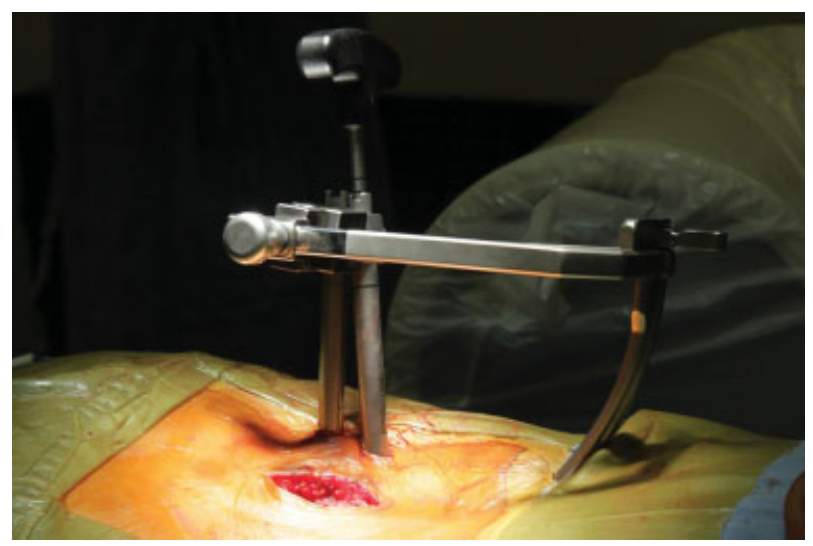

Fig. 4 Mounting of the system with pedicle screw insertion.
There were no cases of bleeding and no need for blood transfusion or hospitalization in the ICU. In one patient aged 66 years, operated for disc herniation correction, there was wound infection, which was treated with antibiotic therapy and resolved well.

All patients recovered well and were discharged in three days postoperatively, with advice to rest, alternating with light walking for a period of 30 days, until returning for consultation. The minimum postoperative follow-up was 19 months, reaching 28 months, with an average of 22.5 months of follow-up in this sample, with no late complications observed.

\section{Discussion}

Since it was first described in 1982 by Harms and Rollinger, the open transforaminal lumbar interbody fusion (TLIF) has eased the pain of many patients worldwide. ${ }^{11}$ Later, minimally invasive surgery emerged and has been contributing in avoiding larger wounds, muscle dissection, and retraction requiring open surgery, with reduced pain, improved quality of life, shorter hospital stay, and less use of analgesics postoperatively. ${ }^{12}$ However, literature reviews have not shown lower complication rates comparing the open and minimally invasive surgeries. ${ }^{13,14}$ Complications, which vary

Table 1 Distribution of surgery indications

\begin{tabular}{|l|l|l|}
\hline Indication & $\mathbf{n}$ & $\%$ \\
\hline Disc herniation & 23 & 54.8 \\
\hline Lumbar canal stenosis & 8 & 19.0 \\
\hline Spondylolisthesis & 6 & 14.3 \\
\hline Fracture in L1 & 3 & 7.1 \\
\hline Fracture in T12 & 1 & 2.4 \\
\hline Fracture in T8 & 1 & 2.4 \\
\hline Total & $\mathbf{4 2}$ & 100.0 \\
\hline
\end{tabular}


Table 2 Distribution of procedures in the sample

\begin{tabular}{|l|l|l|}
\hline Procedure & $\mathbf{n}$ & $\%$ \\
\hline Arthrodesis L2-L3 + decompression & 1 & 2.4 \\
\hline Arthrodesis L3-L4 + L4-L5 + L5-S1, TLIF & 2 & 4.8 \\
\hline Arthrodesis L3-L4, TLIF & 2 & 4.8 \\
\hline Arthrodesis L4-L5 & 1 & 2.4 \\
\hline Arthrodesis L4-L5 + decompression + TLIF & 12 & 28.6 \\
\hline Arthrodesis L4-L5 + L5-S1, TLIF & 7 & 16.7 \\
\hline Arthrodesis L4-L5-S1 + decompression & 3 & 7.1 \\
\hline Arthrodesis L5-S1 + decompression + TLIF & 6 & 14.3 \\
\hline Arthrodesis L5-S1, TLIF & 4 & 9.5 \\
\hline Arthrodesis T11-L1-L2 & 3 & 7.1 \\
\hline Arthrodesis T7-T8-T9 & 1 & 2.4 \\
\hline Total & 42 & 100.0 \\
\hline
\end{tabular}

Abbreviation: TLIF, transforaminal lumbar interbody fusion.

widely, are also not always described in detail in the studies. $^{15,16}$

For any surgical technique, there is a learning curve for the development of technical skills. In the case of spinal surgery, the first requirement is a thorough knowledge of the anatomy of the spine in three dimensions. In contrast to the open procedures, in which the anatomy can be viewed directly, minimally invasive surgery visualization is usually limited to the area of surgical interest and to certain important anatomical landmarks within this limited view. ${ }^{17}$ Familiarity with the anatomy allows the surgeon to perform the procedure safely without exposing structures that are not being treated or that cannot be reached, such as the foramen.

In the case of minimally invasive surgery to treat spinal decompression, arthrodesis, stenosis, and others, the use of a fluoroscope (1-2 minutes of exposure approximately) is required, exposing both patient and surgeon to radiation $^{18,19}$, without solving the problem of lack of visualization of the pedicle. The difficulty starts with the exposure and identification of the entry point for the screw on the facet joint. Further complicated by the fact that the path may vary according to the characteristics of the pedicle bone, which varies for each individual, according to the insertion technique. $^{8}$ Obesity, for example, makes the visualization of structures by fluoroscopy harder, and obese patients bleed more often, disrupting the vision of the structures in the operative field. $^{8}$

Song and Park ${ }^{20}$ state that "while the surgical corridor afforded by the tubular retraction system causes less
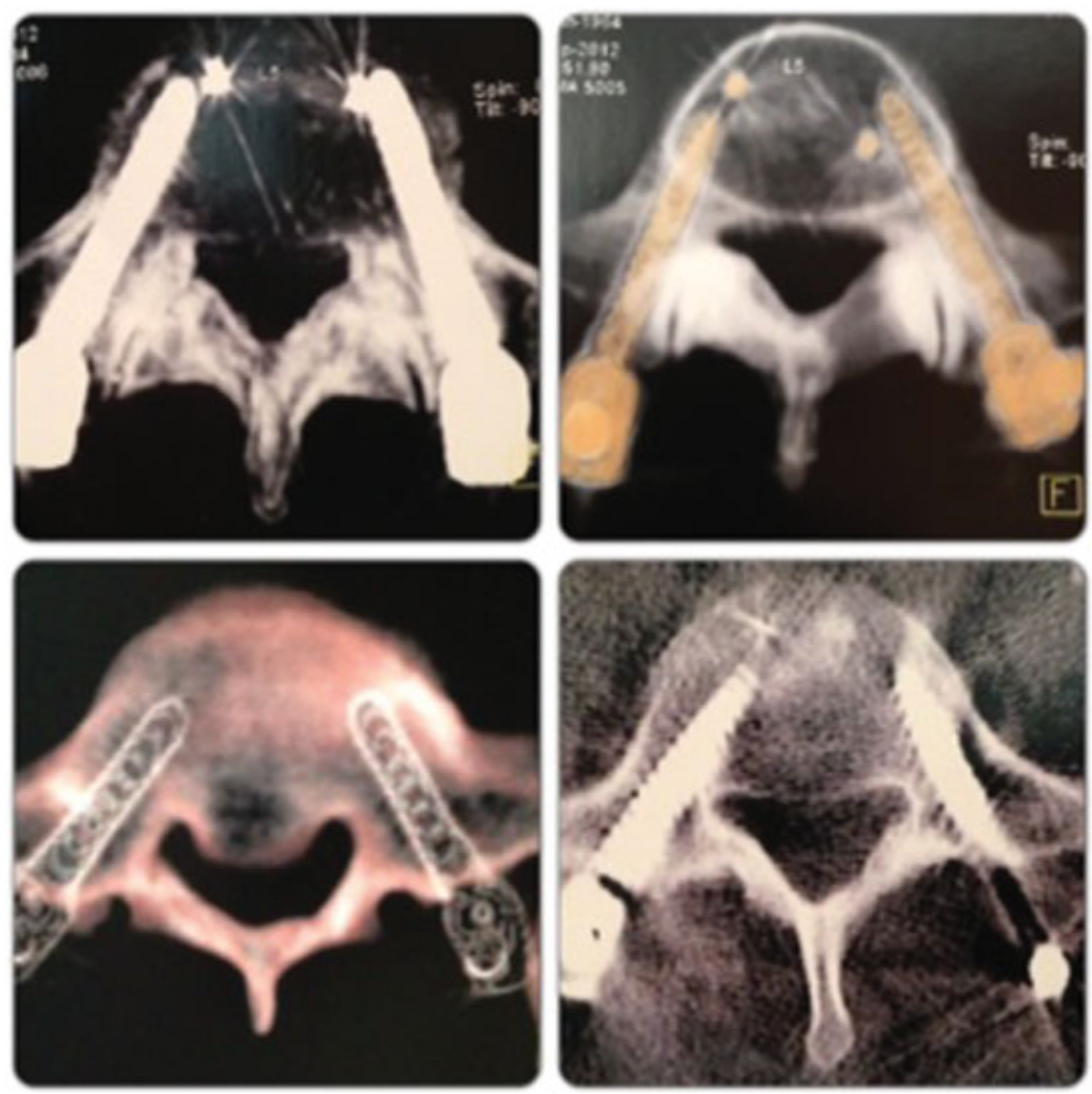

Fig. 5 Axial computed tomography cut of lumbar-sacral spine, showing the correct positioning of screws after surgery with the Scotty Dog technique of fluoroscope monitoring. 
36 Scotty Dog in Operative Procedure of the Spine Garcia et al.

tissue destruction than open approaches" in the minimally invasive techniques, "the narrow and typically deep working channel can also make primary repair of a technically difficult iatrogenic durotomy when using conventional suture and knot-tying techniques". The authors conducted a study precisely on the closure of inadvertent durotomies during minimally invasive surgery of the spine.

In our literature search (- Table 3), ${ }^{8-10,12,21-35}$ attempting to verify the incidence of invasion of the channel using traditional techniques of percutaneous and open surgery, we found that the canal invasion rate can vary from 0 to

Table 3 Prevalence of durotomy or canal invasion in different studies

\begin{tabular}{|c|c|c|c|c|c|}
\hline Reference & $\mathrm{n}$ & Open surgery & TLIF & Notes & $\mathrm{n}^{*}(\%)$ \\
\hline Adogwa et al ${ }^{12}$ & 30 & 15 & 15 & & 0 \\
\hline Bindal et al ${ }^{10}$ & 25 & & 25 & $\begin{array}{l}\text { electroneuromyog- } \\
\text { raphy; } 105 \text { screws } \\
\text { placed }\end{array}$ & $3(12 \%)$ \\
\hline Gu et $\mathrm{al}^{21}$ & 20 & & 20 & $\begin{array}{l}\text { osteoporotic frac- } \\
\text { tures, fluoroscopic } \\
\text { guide }\end{array}$ & $2(10 \%)$ \\
\hline Kelleher et $\mathrm{al}^{22}$ & 75 & & 75 & & $9(12 \%)$ \\
\hline Kim et $\mathrm{al}^{8}$ & 110 & & 110 & $\begin{array}{l}488 \text { screws, one } \\
\text { surgeon }\end{array}$ & $54(49 \%)$ \\
\hline Lee et $\mathrm{al}^{23}$ & 58 & & & & $1(1.7 \%)$ \\
\hline Logroscino et $\mathrm{al}^{24}$ & 20 & & & 80 screws & $1(5 \%)$ \\
\hline Lotfinia et $\mathrm{al}^{9}$ & 53 & & & 247 screws & $\begin{array}{l}28 \text { screws }(11.3 \% \\
\text { screws) }\end{array}$ \\
\hline Lucio et $\mathrm{al}^{25}$ & 210 & 101 & 109 & $\begin{array}{l}\text { complications not } \\
\text { described } \\
\text { (only more fre- } \\
\text { quent in the open } \\
\text { surgery group) }\end{array}$ & ND \\
\hline O'Toole et $\mathrm{al}^{26}$ & 1274 & & 1274 & $\begin{array}{l}\text { complications oth- } \\
\text { er than infections } \\
\text { not described }\end{array}$ & \\
\hline Park, $\mathrm{Ha}^{27}$ & 61 & 29 & 32 & $\begin{array}{l}\text { only one case of } \\
\text { malpositioning }\end{array}$ & 0 \\
\hline Peng et $\mathrm{al}^{28}$ & 29 & 29 & & $\begin{array}{l}\text { only infections de- } \\
\text { scribed } \\
\text { (higher rate in the } \\
\text { open surgery } \\
\text { group) }\end{array}$ & \\
\hline Shunwu et $\mathrm{al}^{29}$ & 62 & 30 & 32 & $\begin{array}{l}\text { only two cases of } \\
\text { malpositioning }\end{array}$ & \\
\hline Siemionow et $\mathrm{al}^{30}$ & 104 & & 104 & & $1(0.96 \%)$ \\
\hline Sugimoto et al ${ }^{19}$ & 49 & & & $\begin{array}{l}128 \text { screws by fluo- } \\
\text { roscopic guidance }\end{array}$ & $\begin{array}{l}3 \text { screws }(2.3 \% \\
\text { screws) }\end{array}$ \\
\hline Wang et $\mathrm{al}^{32}$ & & & & & $\begin{array}{l}4.7 \% \text { and } 4.6 \% \text { of } \\
\text { dura rupture with } \\
\text { TLIF and open } \\
\text { surgery }\end{array}$ \\
\hline Wang et $\mathrm{al}^{33}$ & 52 & 27 & 25 & $\begin{array}{l}\text { only revision } \\
\text { surgeries }\end{array}$ & $\begin{array}{l}\text { and } 3 \text { cases in } \\
\text { each group (18.5\% } \\
\text { and } 12 \%)\end{array}$ \\
\hline Wu et $\mathrm{al}^{34}$ & 151 & & & & $7(4.6 \%)$ \\
\hline Yang et $\mathrm{al}^{35}$ & 21 & & & $\begin{array}{l}7 \text { screws reached } \\
\text { the cortex }\end{array}$ & ND \\
\hline
\end{tabular}

Abbreviations: ND, not described; TLIF, transforaminal lumbar interbody fusion.

*rate of rupture of the pedicle or invasion of the dura or leakage of cement to the canal. 
$49 \%$ of treated patients or from $2.3 \%$ to $11.3 \%$ of inserted screws. Thus, it is difficult to establish the prevalence of invasion, as the studies use different criteria for recording cases and many do not describe the number of patients for which the problem occurred, only the number of screws or vice-versa. Some studies use navigation techniques, whereas others just use the fluoroscopy guide; there is not a standard imaging incidence or technique in all cases, making it difficult to obtain homogeneous results. Feared by surgeons, the complication "foramen invasion" is rarely described in the studies. It probably gets hidden in rates ranging from $0 \%$ to $33 \%$ of complications in minimally invasive surgery and $1.6 \%$ to $16 \%$ in open surgery, ${ }^{14}$ and it is not possible to determine when "complication" means bleeding, infection or foraminal invasion. Usually, it is described as dural tear and, more rarely, it is reported as cases of screw malposition (but without objective criteria for good or bad positioning characterization). Some studies specifically describe the malposition of screws as cortical or in the foramen, and as inframedial, medial, or supramedial. ${ }^{8}$ Others measure the size of the invasion, considering it severe when over $4 \mathrm{~mm}^{9}$

In 2013, Tian et $\mathrm{al}^{15}$ published a meta-analysis trying to compare minimally invasive to open surgery according to many different outcomes. The authors reported that the definition of complications was different between studies, which may have hampered the analysis. Of the 11 included studies, data on complications were available in 10 , and the overall rate was similar between the two groups, involving screws, prosthesis, or bone graft malpositioning, prosthesis migration, rupture of the dura, and infection. There was a higher rate of graft malposition and arthrodesis failure in the group undergoing minimally invasive surgery, but a higher rate of rupture of the dura and infection in the open surgery group, without significant difference between the groups. The rate of dura invasion ranged from $0.6 \%$ to $15.3 \%$.

The visualization technique that we call Scotty Dog is simple, practical, and available in any operating room with fluoroscopy. It has helped us to visualize the pedicle along its entire length and we have not registered any case of invasion foramen using this new way of positioning the fluoroscope. We suggest the conduction of controlled clinical studies, with accurate description of outcomes, to compare the results with the traditional positioning of the fluoroscope and the Scotty Dog.

A Scotty Dog imaging monitoring technique in spine surgery facilitates the visualization of the entire vertebral pedicle, allowing the insertion of screws safely, without invasion of the canal or foramen, as shown in this series.

\section{References}

1 Brown RC, Evans ET. What causes the "eye in the scotty dog" in the oblique projection of the lumbar spine? Am J Roentgenol Radium Ther Nucl Med 1973;118(2):435-437

2 Millard L. "The Scotty dog and his collar". J Ark Med Soc 1976; 72(8):339-340
3 Fish DE, Lee PC, Marcus DB. The S1 "Scotty dog": report of a technique for S1 transforaminal epidural steroid injection. Arch Phys Med Rehabil 2007;88(12):1730-1733

4 Hubbe U, Kogias E, Vougioukas VI. Image guided percutaneous trans-pedicular screw fixation of the thoracic spine. A clinical evaluation. Acta Neurochir (Wien) 2009;151(5):545-549, discussion 549

5 Khoo LT, Palmer S, Laich DT, Fessler RG. Minimally invasive percutaneous posterior lumbar interbody fusion. Neurosurgery 2002;51(5, Suppl)S166-S181

6 Palmisani M, Gasbarrini A, Brodano GB, et al. Minimally invasive percutaneous fixation in the treatment of thoracic and lumbar spine fractures. Eur Spine J 2009;18(Suppl 1):71-74

7 Pelegri C, Benchikh El Fegoun A, Winter M, et al. Ostéosynthèse percutanée des fractures lombaires et thoracolombaires non neurologiques: technique chirurgicale et résultats préliminaires. Percutaneous osteosynthesis of lumbar and thoracolumbar spine fractures without neurological deficit: surgical technique and preliminary results. Rev Chir Orthop Repar Appar Mot 2008; 94(5):456-463

8 Kim MC, Chung HT, Cho JL, Kim DJ, Chung NS. Factors affecting the accurate placement of percutaneous pedicle screws during minimally invasive transforaminal lumbar interbody fusion. Eur Spine J 2011;20(10):1635-1643

9 Lotfinia I, Sayahmelli S, Gavami M. Postoperative computed tomography assessment of pedicle screw placement accuracy. Turk Neurosurg 2010;20(4):500-507

10 Bindal RK, Ghosh S. Intraoperative electromyography monitoring in minimally invasive transforaminal lumbar interbody fusion. J Neurosurg Spine 2007;6(2):126-132

11 Harms J, Rolinger H. [A one-stager procedure in operative treatment of spondylolistheses: dorsal traction-reposition and anterior fusion (author's transl)]. Z Orthop Ihre Grenzgeb 1982; 120(3):343-347

12 Adogwa O, Parker SL, Bydon A, Cheng J, McGirt MJ. Comparative effectiveness of minimally invasive versus open transforaminal lumbar interbody fusion: 2-year assessment of narcotic use, return to work, disability, and quality of life. J Spinal Disord Tech 2011;24(8):479-484

13 Foley KT, Holly LT, Schwender JD. Minimally invasive lumbar fusion. Spine 2003;28(15, Suppl)S26-S35

14 Karikari IO, Isaacs RE. Minimally invasive transforaminal lumbar interbody fusion: a review of techniques and outcomes. Spine 2010;35(26, Suppl)S294-S301

15 Tian NF, Wu YS, Zhang XL, Xu HZ, Chi YL, Mao FM. Minimally invasive versus open transforaminal lumbar interbody fusion: a meta-analysis based on the current evidence. Eur Spine J 2013; 22(8):1741-1749

16 Wong AP, Smith ZA, Lall RR, Bresnahan LE, Fessler RG. The microendoscopic decompression of lumbar stenosis: a review of the current literature and clinical results. Minim Invasive Surg 2012;2012:325095

17 Bresnahan L, Ogden AT, Natarajan RN, Fessler RG. A biomechanical evaluation of graded posterior element removal for treatment of lumbar stenosis: comparison of a minimally invasive approach with two standard laminectomy techniques. Spine 2009;34(1): $17-23$

18 Bindal RK, Glaze S, Ognoskie M, Tunner V, Malone R, Ghosh S. Surgeon and patient radiation exposure in minimally invasive transforaminal lumbar interbody fusion. J Neurosurg Spine 2008; 9(6):570-573

19 Sugimoto Y, Ito Y, Tomioka M, et al. Clinical accuracy of threedimensional fluoroscopy (IsoC-3D)-assisted upper thoracic pedicle screw insertion. Acta Med Okayama 2010;64(3):209-212

20 Song D, Park P. Primary closure of inadvertent durotomies utilizing the U-Clip in minimally invasive spinal surgery. Spine 2011; 36(26):E1753-E1757 
21 Gu Y, Zhang F, Jiang X, Jia L, McGuire R. Minimally invasive pedicle screw fixation combined with percutaneous vertebroplasty in the surgical treatment of thoracolumbar osteoporosis fracture. J Neurosurg Spine 2013;18(6):634-640

22 Kelleher MO, Timlin M, Persaud O, Rampersaud YR. Success and failure of minimally invasive decompression for focal lumbar spinal stenosis in patients with and without deformity. Spine 2010;35(19):E981-E987

23 Lee JC, Jang HD, Shin BJ. Learning curve and clinical outcomes of minimally invasive transforaminal lumbar interbody fusion: our experience in 86 consecutive cases. Spine 2012;37(18):1548-1557

24 Logroscino CA, Proietti L, Pola E, Scaramuzzo L, Tamburrelli FC. A minimally invasive posterior lumbar interbody fusion for degenerative lumbar spine instabilities. Eur Spine J 2011;20(Suppl 1):S41-S45

25 Lucio JC, Vanconia RB, Deluzio KJ, Lehmen JA, Rodgers JA, Rodgers $W$. Economics of less invasive spinal surgery: an analysis of hospital cost differences between open and minimally invasive instrumented spinal fusion procedures during the perioperative period. Risk Manag Healthc Policy 2012;5:65-74

26 O'Toole JE, Eichholz KM, Fessler RG. Surgical site infection rates after minimally invasive spinal surgery. J Neurosurg Spine 2009; 11(4):471-476

27 Park Y, Ha JW. Comparison of one-level posterior lumbar interbody fusion performed with a minimally invasive approach or a traditional open approach. Spine 2007;32(5):537-543

28 Peng CW, Yue WM, Poh SY, Yeo W, Tan SB. Clinical and radiological outcomes of minimally invasive versus open transforaminal lumbar interbody fusion. Spine 2009;34(13):1385-1389
29 Shunwu F, Xing Z, Fengdong Z, Xiangqian F. Minimally invasive transforaminal lumbar interbody fusion for the treatment of degenerative lumbar diseases. Spine 2010;35(17):1615-1620

30 Siemionow K, Pelton MA, Hoskins JA, Singh K. Predictive factors of hospital stay in patients undergoing minimally invasive transforaminal lumbar interbody fusion and instrumentation. Spine 2012;37(24):2046-2054

31 Sugimoto Y, Ito Y, Tomioka M, et al. Upper lumbar pedicle screw insertion using three-dimensional fluoroscopy navigation: assessment of clinical accuracy. Acta Med Okayama 2010;64(5): 293-297

32 Wang J, Zhou Y, Zhang ZF, Li CQ Zheng WJ, Liu J. Comparison of one-level minimally invasive and open transforaminal lumbar interbody fusion in degenerative and isthmic spondylolisthesis grades 1 and 2. Eur Spine J 2010;19(10):1780-1784

33 Wang J, Zhou Y, Zhang ZF, Li CQ, Zheng WJ, Liu J. Minimally invasive or open transforaminal lumbar interbody fusion as revision surgery for patients previously treated by open discectomy and decompression of the lumbar spine. Eur Spine J 2011; 20(4):623-628

34 Wu WJ, Liang Y, Zhang XK, Cao P, Zheng T. Complications and clinical outcomes of minimally invasive transforaminal lumbar interbody fusion for the treatment of one- or two-level degenerative disc diseases of the lumbar spine in patients older than 65 years. Chin Med J (Engl) 2012;125(14):2505-2510

35 Yang WE, Ng ZX, Koh KM, et al. Percutaneous pedicle screw fixation for thoracolumbar burst fracture: a Singapore experience. Singapore Med J 2012;53(9):577-581 